\title{
THE MAREVA INJUNCTION COMES TO ALBERTA: THE BRADLEY RESOURCES CASE
}

\author{
FREDERICK ERICKSON*
}

\begin{abstract}
This article examines Bradley Resources Corporation v. Kelvin Energy Ltd., the first Alberta Court of Appeal decision dealing with the Mareva injunction. In doing this, the author considers the use and availability of the Cyanamid injunction as well as the Mareva injunction. As well, the author contemplates the possibility of a Bradley injunction.
\end{abstract}

\section{INTRODUCTION}

There are few recent judicial innovations today as significant as the Mareva injunction. Barely a decade old, the Mareva injunction has already made a substantial impact on credit collection practices in Alberta. As most commercial lawyers will know, the Mareva injunction is intended to protect creditors from unscrupulous debtors who attempt to arrange their financial affairs before the creditors obtain judgment in such a manner so as to insulate themselves from enforcement of that judgment should the creditors succeed. In other words, the Mareva is designed to prevent debtors from having the opportunity to hide their assets before a creditor has a chance to execute against them. Given the generally worsening economic climate in Western Canada coupled with the resultant increase in defaults and bankruptcies, it is not unrealistic to expect the Mareva injunction to play an even larger role in commercial credit enforcement practices in the forseeable future. Consequently it is important for the commercial lawyer to have a good working knowledge of this powerful remedy.

It is with this backdrop in mind that the Alberta Court of Appeal judgment in Bradley Resources Corporation v. Kelvin Energy Ltd. ' will be discussed. Bradley Resources was decided shortly after the Supreme Court of Canada judgment in Aetna Financial Services Ltd. v. Feigelman, ${ }^{2}$ the leading case in Canada with respect to Mareva injunctions. Furthermore, Bradley Resources represents the first opportunity that the Court of Appeal has had to comment upon the Mareva injunction. Consequently, for both of these reasons, the Court of Appeal's comments should be of considerable interest to the Alberta practitioner. Although the end result arrived at by the court is hard to criticize, the reasoning employed by the court unfortunately is not entirely satisfactory. This may be due in part to a rather restrictive interpretation placed by the Court of Appeal on the Supreme Court's decision in Feigelman. The objective of this article is to critically examine the reasons for judgment given by the Alberta Court of Appeal in Bradley Resources. Hopefully any confusion or misconceptions generated by the court's judgment in Bradley Resources will be cleared up to some extent. Furthermore, by going through this analysis the reader should acquire a more subtle understanding of the nature and scope of the Mareva injunction, which itself is invaluable given the uncertain future facing Alberta and Western Canada.

* Graduate of the MBA-LL.B. program at the University of Alberta, 1987.

1. (1985) 18 D.L.R. (4th) 468, [1985] 5 W.W.R. 763, 61 A.R. 169, 39 Alta. L.R. (2d) 193. Leave to appeal to the Supreme Court of Canada refused June 25, 1985; 63 A.R. 320.

2. [1985] 1 S.C.R. 2, [1985] 2 W.W.R. 97. 


\section{THE DECISION}

\section{A. THE FACTS}

Kelvin Energy Ltd., the appellant, had sold the entirety of its corporate undertaking to an undisclosed purchaser for thirty-five million dollars. Bradley Resources Corporation, the respondent, was a minority shareholder, holding 428,922 shares in the appellant company. Bradley had exercised its right to dissent to the sale pursuant to sections 183(1) and 184(1)(e) of the Alberta Business Corporations Act ${ }^{3}$ and subsequently sought to enforce its right to have the appellant redeem its shares at fair market value. ${ }^{4}$ There was the usual disagreement as to what was the proper fair market value; Bradley claimed the fair market value to be between \$3.38 and \$3.52 per share, while Kelvin, not unexpectedly, argued that the value should be substantially lower at $\$ 1.30$. Bradley made an application under s. 184(6) to the Court of Queen's Bench for an appraisal of the shares' fair market value.

In the interim, Bradley had discovered that Kelvin had transferred fourteen million dollars, along with its head office, from Calgary to Vancouver. Frightened that Kelvin's assets might evaporate before its shares were redeemed, Bradley applied ex parte for a Mareva injunction. The interlocutory relief was granted, prohibiting Kelvin from disposing of its assets prior to the completion of the appraisal proceedings. Kelvin subsequently applied to have the injunction lifted. The chambers judge ordered the injunction to be set aside on the basis that counsel for Kelvin would give an undertaking on behalf of Kelvin to prevent the declaration of dividends or allow any other form of disposal of Kelvin's assets.

As subsequent events revealed, counsel for Kelvin never intended to agree to such a broad undertaking and as a result appealed the order lifting the injunction to the Alberta Court of Appeal. It is the Court of Appeal's judgment in this appeal which constitutes the main focus of this paper. ${ }^{5}$ Kerans J.A., with McDermid and Harradence JJ.A. concurring, acknowledged the misunderstanding on the part of the chambers judge and on that basis vacated the order setting aside the injunction as it clearly relied upon counsel's presumed undertaking. ${ }^{6}$

That being the case, the issues pertaining to whether the injunction should be lifted had to be reargued. Rather than send the matter back to chambers, counsel requested that the Court of Appeal rehear the matter; the court somewhat hesitantly obliged.' As a result, the three judges from Alberta's highest court in effect stepped into the shoes of a chambers judge, and proceeded to hear the matter on its merits. It is with this part of the judgment that we are concerned.

3. S.A. 1981 , c. B-15.

4. Id. s. $184(3)$.

5. It is interesting to note that the somewhat peculiar history of this action, particularly the fact that the appellant Kelvin Energy Ltd. had appealed an order in their favour, led to confusion amongst editors of the Alberta Law Reports, the Alberta Reports and the Western Weekly Reports, all of whom described the judgment as one concerning an "Appeal from order granting Mareva injunction", when in fact what was appealed was an order setting aside the Mareva injunction; see supra n. 1 at 764 W.W.R., 169 A.R., 194 Alta. L.R.

6. Supra n. 1 at 470 D.L.R., 765 W.R.R., 170 A.R., 195 Alta. L. R.

7. Id. 


\section{B. THE REASONS FOR JUDGMENT}

The Alberta Court of Appeal concluded that Bradley was entitled to interlocutory injunctive relief; although a Mareva injunction was not available on the facts of the case, it was quite clear to the court that some form of interim relief was necessary. The court therefore prohibited Kelvin from disposing of its assets until the appraisal proceedings were completed, without first obtaining court approval. ${ }^{8}$

Mr. Justice Kerans, speaking for the court, looked firstly at the availability of what his Lordship termed a Cyanamid injunction, undoubtedly referring to the House of Lord's landmark decision in American Cyanamid v. Ethicon Ltd. ${ }^{9}$ It was conceded by counsel for Bradley that the grounds for a Cyanamid injunction had not been established. Proof of irreparable harm to the applicant, should the injunction be refused, is a prerequisite to the granting of this type of injunction; in the case at bar, all that could be established was some fear or apprehension of irreparable damage if Kelvin was not restrained from dealing with its assets. ${ }^{10}$

Kerans J.A. then proceeded to examine whether a Mareva injunction was available on the facts. After quoting a portion of the Supreme Court of Canada's judgment in Aetna Financial Services Ltd. v. Feigelman" pertaining to the inapplicability of Mareva injunctions in situations where the debtor merely transferred assets from one province to another, his Lordship concluded that the transfer by Kelvin of a substantial portion of its assets from Alberta to British Columbia "should not trigger a Mareva injunction."'2 It is this part of the learned Judge's reasoning which, it is respectfully submitted, does not withstand close scrutiny, as will be discussed shortly.

Having discarded the Mareva injunction, Mr. Justice Kerans then looked at the possibility of a quia timet injunction, which differs from a Cyanamid injunction in that the former is intended to protect against feared future harm, whereas the latter, it is presumed, is designed for situations involving certain future harm, should the injunction not be granted. However, as was the case with both the Cyanamid and Mareva injunctions, Kerans J.A. once again concluded that Bradley had not established the necessary prerequisites for obtaining a quia timet order. The court must find a "very high probability of future harm", ${ }^{13}$ which in his Lordship's opinion did not exist in the case at bar; while there was some suspicion that Kelvin may dispose of its assets prior to trial, the suspicion was not sufficient to justify a quia timet order. ${ }^{14}$

Having determined that none of the conventional interlocutory injunctions were available, Kerans J.A. proceeded to break what he thought was new ground. His Lordship examined the nature of the right given to

\footnotetext{
8. Id. at 472 D.L.R., 768 W.W.R., 172 A.R., 197 Alta. L.R.

9. [1975] 1 All E.R. 504.

10. Supra n. 1 at 470 D.L.R., 765 W.W.R., 170 A.R., 195 Alta. L.R. The court's reasoning with respect to "Cyanamid" injunctions will be examined in more detail later in this paper.

11. Supra n. 2.

12. Supra n. 1 at 471 D.L.R., 766 W.W.R., 170 A.R., 195 Alta. L.R.

13. Id.

14. Id. àt 471 D.L.R., 766 W.W.R., 170 A.R., 196 Alta. L.R.
} 
minority shareholders under s. 184 of the Business Corporations Act. The dissentient shareholder's right of redemption in situations involving fundamental change ${ }^{15}$ in the corporation did not exist at common law, where the general rule of majority rule was subject to few exceptions. As his Lordship reasoned: 16

It would be unthinkable if this new right could be effectively destroyed or put at a substantial risk during the period before final judgment and payment precisely because the company proceeds down the new road. If those in control dissipate the proceeds of the sale of the company undertaking before payment here, the right granted Bradley is effectively lost.

Confronted with the unavailability of conventional forms of interlocutory relief, Kerans J.A. chose to exercise the court's "undoubted power of injunction" to grant Bradley interim protection, "17 prohibiting Kelvin from dealing with its assets without prior court approval. Mr. Justice Kerans essentially fashioned a new form of interlocutory injunctive relief, available where there existed a "substantial risk" that the shareholder's right to be bought out would be rendered meaningless if the order was not made. ${ }^{18}$

\section{COMMENTARY}

The result arrived at by the Court of Appeal is hard to argue with on its merits. It is undoubtedly justifiable that the dissenting shareholders should have their right to bail out protected, given the substantial risk of dissipation found by the court to be present. To deny relief in such circumstances would have in effect left the door wide open for unscrupulous corporate raiders to swoop down on an undervalued target, acquire control, liquidate its assets, and exit the scene leaving behind little, if any value against which dissenting shareholders could exercise their s. 184 rights. The need for injunctive protection in these situations is quite apparent.

Unfortunately, the reasoning employed by Mr. Justice Kerans in holding that a Mareva injunction was not available in the circumstances is less than satisfactory. Furthermore, it is submitted that the type of injunctive relief actually granted by the learned Judge is, for all intents and purposes a Mareva injunction. These arguments shall form the core of this paper. However, before delving into the Mareva issues, a few comments should be made concerning what Mr. Justice Kerans terms the "Cyanamid" injunction.

\section{A. THE CYANAMID INJUNCTION}

As mentioned above, Kerans J.A. concluded that a Cyanamid injunction was not available on the facts of the case. As his Lordship phrased it,

15. Section 184(1) gives a list of fundamental changes which allow a dissenting shareholder to have his shares redeemed by the corporation. These include changing the capital structure, changing the restrictions on the types of business the corporation may carry on, amalgamations, continuing under the laws of another jurisdiction and the sale, lease or exchange of all or substantially all of its property.

16. Supra n. 1 at 472 D.L.R., 767 W.W.R., 171 A.R., 196 Alta. L.R.

17. Id. at 472 D.L.R., 767 W.W.R., 171 A.R., 197 Alta. L.R.

18. Id. 
". . . a case for a Cyanamid injunction has not been made out because . . . he [Bradley's counsel] cannot prove irreparable harm; he can only show some apprehension of irreparable harm."' 19 This is the only reference Kerans J.A. made with respect to the Cyanamid injunction.

While it is not entirely clear to this writer what is encompassed by a Cyanamid injunction, the name is undoubtedly referring to the House of Lords decision in American Cyanamid v. Ethicon Ltd. ${ }^{20}$ This case examined what the proper threshold should be in applications for interlocutory relief in general. To rephrase the issue, to what standard must the plaintiff establish his legal claim against the defendant before being entitled to consideration for interlocutory relief. For example, in a typical debt action, what burden must the plaintiff creditor discharge in order to satisfy the court that he has a legally enforceable debt against the defendant debtor? Prior to American Cyanamid the prevailing opinion was that the plaintiff had to establish a prima facie case against the defendant in that if the case went to trial on the same evidence, the plaintiff would succeed on a balance of probabilities. ${ }^{21}$ The alternative view was that all that the plaintiff was required to show was that he had an "arguable case" or was "reasonably capable of succeeding" at trial. Lord Diplock, speaking for the House, roundly rejected the prevailing view and proceeded to state what has become the standard formulation:22

The Court no doubt must be satisfied that the claim is not frivolous or vexatious; in other words, that there is a serious question to be tried.

It should be noted that once the plaintiff satisfies the court that it has a legally enforceable claim against the defendant, the plaintiff must still establish the need for interlocutory relief, or in other words, that irreparable harm would be incurred if the relief were not issued which could not be adequately compensated for by an award of damages at trial. ${ }^{23}$

The courts were initially reluctant to adopt the new formulation, but eventually the British and most Canadian courts began to recognize and employ the American Cyanamid threshold. The Supreme Court of Canada recently acknowledged American Cyanamid as the general principle in Canada. ${ }^{24}$ In Alberta, the Court of Appeal adopted the American Cyanamid formulation in Erickson v. Wiggins, ${ }^{25}$ giving scant consideration to the issues. Erickson was subsequently confirmed in both Law Society of Alberta v. Black \& Company ${ }^{26}$ and Ominayak v. Norcen Energy Resources. ${ }^{27}$ Mr. Justice Kerans, in Black \& Company, described the proce-

19. Id. at 470 D.L.R., 766 W.W.R., 170 A.R., 195 Alta. L.R.

20. Supra n. 9.

21. As described by Professor Grant Hammond in "Interlocutory Injunctions: Time for a New Model?" (1980) 30 U. of T. L.J. 240 at 251, lawyers began to use the interlocutory proceedings as an efficient and cost effective method for resolving disputes, given that the parties would be able to obtain through the proceedings an impression as to how the court viewed the evidence.

22. Supran. 9 at 510.

23. Id.

24. Aetna Financial Services Ltd. v. Feigelman, supra n. 2 at 10 S.C.R., 104 W.W.R.

25. [1980] 6 W.W.R. 188.

26. (1984) 29 Alta. L.R. (2d) 326 (C.A.).

27. [1985] 3 W.W.R. 193, 58 A.R. 161,36 Alta. L.R. (2d) 137 (C.A.). 
dure for obtaining an interlocutory injunction in Alberta in the following terms: ${ }^{28}$

The tri-partite sequential test of Cyanamid requires, for the granting of such an order, that the applicant demonstrate, firstly, that he has a serious issue to be tried; secondly, that he would suffer irreparable harm if no order was granted; and thirdly, that the balance of convenience considering the total situation of both parties favours the order.

This formulation has recently been applied in several reported decisions. ${ }^{29}$

The purpose of this rather brief discussion of the American Cyanamid decision and its presence in Alberta is two-fold. Firstly, it is hoped that the discussion assists the reader in acquiring some insight into what may be encompassed by the term "Cyanamid" injunction. Secondly, the discussion provides a backdrop for the following comments regarding $\mathrm{Mr}$. Justice Kerans' remarks concerning the availability of a Cyanamid injunction on the facts before him.

As mentioned previously, Kerans J.A. concluded that since Bradley could not establish irreparable harm but only some fear of irreparable harm, Bradley was not entitled to a Cyanamid injunction. This requirement of irreparable harm can be traced back to the excerpt from Black \& Company set out above, wherein the second part of the three stage process was the establishment of irreparable harm if the injunction were not granted. Given the finding of fact that only "some apprehension of irreparable harm" existed, one cannot argue with the learned justice's conclusion that the case for a Cyanamid injunction had not been established by Bradley. It is submitted however, that even if Bradley had proven irreparable harm, a Cyanamid injunction should still not have been available, given that the injunctive relief applied for sought a freezing of Kelvin's assets prior to trial.

It had been settled law for close to a century that a creditor could not obtain an injunction to prevent a man from disposing of his assets pendente lite.$^{30}$ It was regarded as inherently unjust to tie up a person's assets prior to a final adjudication of the parties' respective rights. In effect, the court sought to prevent execution of a debt before judgment. An exception to this general proposition emerged recently in the form of what is commonly referred to as the Mareva injunction. ${ }^{31}$ As discussed in the next part of this paper, a Mareva injunction is only available under certain judicially prescribed circumstances, namely where there is a genuine risk of dissipation of the debtor's assets with the intent of defeating the creditor. Unless the plaintiff can fit his case within the Mareva requirements or falls within one of the other narrow exceptions to the general rule,$^{32}$ he will be unable to prevent the defendant from disposing of his assets pendente lite.

28. Supra n. 26 at 329.

29. See: Ed Miller Sales v. Caterpillar Tractor (1986) 67 A.R. 187; London Drugs v. City of Red Deer (1986) A.W.L.D. 396; Wood v. C.B.C. (1986) A.W.L.D. 426; Peters v. Thompson (1986) A.W.L.D. 169 (C.A.); Royal Trust Corp. v. Law Society of Alta. (1985) 36 Alta. L.R. (2d) 393.

30. Lister \& Co. v. Stubbs (1890) 45 Ch.D. 1; Robinson v. Pickering (1881) 16 Ch.D. 660.

31. Aetna v. Feigelman, supra n. 2 at 37 S.C.R., 127 W.W.R., wherein Estey J. refers to the Mareva as a limited exception to the general rule.

32. Estey J. enumerates these narrow exceptions in Feigelman, id. at 13 S.C.R., 107 W.W.R. 
The reader should recall that Bradley was essentially asking for an injunction to tie up Kelvin's assets until an appraisal could be rendered. Given the general rule prohibiting the freezing of a defendant's assets pendente lite, Bradley would not be entitled to the remedy requested even if irreparable harm (as opposed to a mere apprehension thereof) were proven, unless the requirements for a Mareva injunction were established. Therefore, unless the Cyanamid injunction also encompasses the Mareva injunction, Bradley would not have been any further ahead, in terms of obtaining a Cyanamid injunction, if it had established irreparable harm. However, it is not possible that the Cyanamid injunction encompasses the Mareva injunction. The Cyanamid injunction is available according to Kerans J.A. only where there is proof that irreparable harm will occur if the injunction is not granted. On the other hand, the case law clearly holds that a Mareva is available even where there is only a genuine risk that the plaintiff will suffer irreparable harm..$^{33}$

To summarize, while Kerans J.A. is correct when he concludes that a Cyanamid injunction is not available on the facts because there exists only an apprehension of irreparable harm, it is suggested with deference that his reasoning is not complete. A Cyanamid injunction should also not be available for the reason that the relief applied for is intended to tie up the defendant's assets pendente lite. It is hoped that this discussion gives the reader a better understanding of what is likely encompassed in the Cyanamid injunction, the Bradley Resources case being the first encounter this writer has had with such terminology.

\section{B. THE MAREVA INJUNCTION}

A more interesting aspect of the Bradley decision relates to the appellate court's comments regarding the availability of a Mareva injunction in the case before them. The reader should recall the court's conclusion that a Mareva was not available, reasoning that a removal of Kelvin's assets from Alberta to British Columbia did not constitute a removal from jurisdiction as defined in the Feigelman decision. It is respectfully submitted that both the conclusion and reasoning used to support it are somewhat suspect and are therefore open to attack. This may be due, in part, to a less that complete understanding of the nature of the Mareva injunction and the law governing its issuance as canvassed by the Supreme Court in Feigelman. Therefore it is proposed that before commenting on the Alberta Court of Appeal's treatment of the Mareva injunction, a brief synopsis of the law regarding Mareva injunctions in Canada be presented. This will provide the background necessary for understanding the comments to follow concerning the Bradley case, and in addition may clear up any questions the reader may have had regarding the scope and usage of this relatively new form of prejudgment relief. 


\section{Mareva Injunctions in Canada}

The history of the Mareva injunction has been well documented in many judgments and treatises, ${ }^{34}$ and although a detailed examination into the creation and evolution of this judge-made remedy would undoubtedly be a fascinating study in and of itself, such is beyond the scope of this paper. It is sufficient to observe that the Mareva injunction is still relatively young, having been developed in England in 1975 pursuant to a trilogy of decisions of the English Court of Appeal written, not surprisingly, by Lord Denning M.R. ${ }^{35}$ It made its appearance in Canada as early as 1979 in a British Columbia matrimonial property suit, ${ }^{36}$ and has recently been given close consideration by the Supreme Court of Canada in Feigelman. The Mareva injunction was in essence the English Court of Appeal's response to a growing discontent in the international commercial community with the lack of effective prejudgment remedies. There was little a creditor could do to prevent his debtor from spiriting away assets in such a manner that by the time judgment was obtained, the assets were far beyond the reach of the law. The need for an effective prejudgment remedy provided the fuel necessary to drive the almost amazing growth in popularity experienced by the Mareva injunction. During this period of growth however, the nature of the remedy was continually evolving to balance the interests of the debtor and creditor, and continues to do so today. One should keep in mind while reading this discussion that the law is in a constant state of evolution and therefore may not be the same tomorrow as it is today.

It is now beyond argument that the superior courts of each province in Canada have the jurisdiction to grant interlocutory relief in the form of a Mareva injunction. Prior to Feigelman there had been some doubt, but Mr. Justice Estey, writing the reasons for judgment for the Supreme Court in Feigelman, placed the issue beyond doubt in concluding such jurisdiction existed within the Canadian courts. ${ }^{37}$ The basis of the court's jurisdiction in Alberta is s. 13(2) of the Judicature Act: $:^{38}$

An order in the nature of a mandamus or injunction may be granted or a receiver appointed by an interlocutory order of the Court in all cases in which it appears to the Court to be just or convenient that the order should be made, and the order may be made either unconditionally or on any terms and conditions the Court thinks just.

It should be observed that the jurisdiction is almost completely discretionary, therefore the applicant must satisfy the court that a Mareva injunction would be "just or convenient" in the circumstances. While several judgemade conditions have been developed to assist the court in applying its discretion, one must always be mindful of the fact that the court's jurisdiction is discretionary, and need not be exercised, even though all of the judge-made conditions may have been satisfied.

34. See Aetna v. Feigelman, supra n. 2 and C.R.B. Dunlop, Creditor - Debtor Law in Canada - Supplement (1984) 51-75, for two of the more thorough discussions.

35. Nippon Yusen Kaisha v. Karageorgis [1975] 3 All E.R. 282 (C.A.); Mareva Compania Naviera SA v. International Bulkcarriers SA [1980] 1 All E.R. 213 (C.A.); Rasu Maritima SA v. Pertambangan [1977] 3 All E.R. 324 (C.A.).

36. Manousakis v. Manousakis (1979) 10 B.C.L.R. 21 (S.C.).

37. Supra n. 2 at 15 S.C.R., 108 W.W.R.

38. R.S.A. 1980 , c. J-1. 
The first hurdle which the applicant must clear when making application for a Mareva injunction is the establishment of a legally enforceable claim against the debtor. There is some debate over what standard of proof must be met before this requirement is satisfied. English courts have applied the American Cyanamid formulation in requiring that the applicant establish a "good arguable case" against the debtor ${ }^{39}$ On the other hand, the Ontario Court of Appeal has expressed a somewhat higher burden by requiring that the applicant establish a "strong prima facie case" against the debtor. ${ }^{40}$ The Supreme Court of Canada in Feigelman acknowledged the issue and quoted both formulations, yet failed to adopt either as the approach to follow in Canada. ${ }^{41}$ Whatever the standard, one may question whether it is realistic in practice for a court to distinguish between the two competing thresholds, given that application is made ex parte on the basis of affidavit evidence. ${ }^{42}$

The applicant must have a cause of action justiciable in the court where he is making the application. ${ }^{43}$ The mere fact that the defendant debtor has exigible assets in the jurisdiction is not sufficient to support a Mareva application. The court must also have jurisdiction over the applicant's claim.

The cause of action need not be one for a debt or liquidated demand. As Estey J. notes in Feigelman, ${ }^{44}$ the applicant's claim ". . . no longer need be limited to debt or liquidated damages." The range of actions in which Mareva injunctions have been issued has expanded beyond debt, including matrimonial property partitions ${ }^{45}$ wrongful dismissal actions, ${ }^{46}$ and personal injury claims for unliquidated damages. ${ }^{47}$

The court's discretion to grant a Mareva injunction is not restricted by the availability of other prejudgment remedies. ${ }^{48}$ Therefore, even though the applicant may be entitled to a writ of attachment under the absconding debtor provisions, ${ }^{49}$ or a garnishee summons before judgment, ${ }^{50}$ he may opt for the flexibility of a Mareva injunction. There are at least three reasons why an applicant would select the Mareva injunction over the conventional prejudgment remedies. Firstly, it is generally accepted that the writ of

39. See Rasu Martima SA v. Pertambangan, supran. 35 at 334; Barclay-Johnson v. Yuill [1980] 3 All E.R. 190 at 195 (Ch.D.).

40. Chitel v. Rothbart (1982) 141 D.L.R. (3d) 268 at 278 (Ont. C.A.).

41. Supra n. 2 at 27 S.C.R., 118 W.W.R. Other writers have expressed an opinion that the Supreme Court adopted the Chitel "strong prima facie case" threshold; see McAllister, "Supreme Court firmly establishes Mareva injunction", 4:20 Ont. Lawyers Weekly 19; Thompson, "The Mareva Injunction in Canada", 4:6 Nat. B.L. Rev. 108.

42. For discussion on this point, see Meridian Technologies v. Northern Telecom (1985) 5 C.P.R. (3d) 145 at 152 (Ont. H.C.J.). See also Berryman, "Anton Piller Injunctions: An Update" (1985) 2 I.P.J. 49 at 54; Spry, "The Myth of the Prima Facie Case" (1981) 55 Aust. L.J. 784.

43. The Siskina [1977] 3 All E.R. 803 (H.L.); Suncorp Realty Inc. v. PLN Investments Inc. [1986] 1 W.W.R. 619 at 632 (Man. Q.B.).

44. Supra n. 2 at 24 S.C.R., 116 W.W.R.

45. Manousakis v. Manousakis, supra n. 36.

46. Van Brugge v. Arthur Frommer Int. Ltd. (1982) 35 O.R. (2d) 333 (H.C.J.).

47. Allen v. Jambo Hldgs. Ltd. [1980] 2 All E.R. 502, [1980] 1 W.L.R. 1252 (C.A.).

48. Supra n. 2 at 29 S.C.R., 120 W.W.R.

49. Alberta Rules of Court, R. 485.

50. Id. R. 470(1). 
attachment cannot bind land owned by the debtor, whereas it appears quite clear, both in practice and in the reported decisions, ${ }^{\text {s1 }}$ that a Mareva injunction may be used to bind the debtor's real property. Secondly, joint bank accounts cannot be attached by a garnishee summons where the applicant's claim is against only one of the joint depositors. ${ }^{32}$ However, there is English precedent suggesting that joint bank accounts can be caught by a Mareva injunction..$^{3}$ Finally, in order to obtain a writ of attachment, a corroborating affidavit given by a person well acquainted with the debtor is required..$^{54}$ This rather difficult obstacle is not a prerequisite for the obtaining of a Mareva injunction.

Once the applicant has satisfied the court that he has a legally enforceable claim against the debtor, he must then proceed to establish that the balance of convenience lay in favour of granting the injunction. ${ }^{35}$ This requirement is standard procedure for obtaining any type of interlocutory injunction. The "overriding consideration", as Estey J. describes it: ${ }^{56}$

... is that the defendant threatens to so arrange his assets as to defeat his adversary, should that adversary ultimately prevail and obtain judgment, in any attempt to recover from the defendant on that judgment.

In other words, there must be a sufficiently high risk that the debtor will hide his assets in such a manner so as to render any subsequent judgment against him nugatory.

Although the Mareva injunction was originally intended to prevent debtors from removing their assets from the jurisdiction prior to judgment, its scope eventually widened to include dissipation within jurisdiction as well..$^{57}$ It is clear from the Supreme Court's decision in Feigelman that the Mareva covers both removal from as well as dissipation within jurisdiction of the debtor's assets prior to judgment..$^{38}$ The main thrust of the Feigelman decision concerned the definition of "removal from jurisdiction" in the federal context. Mareva jurisprudence having developed in England, a unitary state, the question as Mr. Justice Estey saw it was ". . . do the principles, as developed in the United Kingdom courts, survive intact a transplantation from that unitary state to the federal state of Canada?" 99 More specifically, does the removal of assets from one province to another province in the federal system justify the granting of a Mareva injunction? The Supreme Court concluded that the removal from one province to another by itself was not sufficient to support a Mareva

51. Humphreys v. Buraglia (1982) 135 D.L.R. (3d) 535 (N.B.C.A.). In discussion with practitioners, they have expressed the ability to register Mareva injunctions at the Land Titles Office.

52. Banff Park Savings \& Credit Union Ltd. v. Rose (1982) 22 Alta. L.R. (2d) 81 (C.A.), which concerned a garnishee summons issued after judgment.

53. Z Ltd. v. A-Z and AA-LL [1982] Q.B. 558 at 577 (per Lord Denning), at 591 (per Kerr L.J.) (C.A.).

54. Alberta Rules of Court, R. $485(b)$.

55. Supra n. 2 at 24 S.C.R., 116 W.W.R.

56. Id.

57. See Chartered Bank v. Daklouche [1980] I All E.R. 205 (C.A.); Barclay-Johnson v. Yuill [1980] 3 All E.R. 190 (Ch.D.); Prince Abdul Rahman v. Abu-Taha [1980] 3 All E.R. 409 (C.A.), for the evolution in England.

58. Supra n. 2 at 25 S.C.R., 117 W.W.R.

59. Id. at 34 S.C.R., 124 W.W.R. 
application due to the existence of reciprocal enforcement of judgment legislation. This legislation allows the applicant to enforce his judgment obtained in one province against the debtor's assets residing in a reciprocating province. Recalling that the purpose of the Mareva injunction is to protect the applicant from suffering irreparable harm, the mere transfer of assets from one province to another would not cause irreparable harm to the applicant, given the existence of reciprocal enforcement legislation. ${ }^{60}$ As a consequence, in order to constitute a "removal from jurisdiction" for Mareva purposes the removal must place the assets in a jurisdiction where the judgment obtained by the applicant could not be enforced. It is important to note however that the Mareva is still available in circumstances where the assets were moved from one province to another, but only where done in such a manner as to constitute dissipation within jurisdiction for the purpose of defeating the creditor. Whether the assets were removed from the jurisdiction or dissipated within the jurisdiction, the bottom-line must be that if the injunction were not granted, any judgment obtained by the applicant would be stultified.

In theory the Mareva injunction should not be able to prevent a debtor from dealing with his assets in the ordinary course of business, given that the requisite intent to defeat a person's creditors is not present.${ }^{6}$ However, in practice it is often difficult to distinguish between transactions made in the ordinary course of business and those designed to insulate one's assets from legal process.

The applicant must satisfy the court that "... there is a genuine risk of disappearance of assets, either inside or outside the jurisdiction . . "? as noted by Estey $\mathrm{J}$. in Feigelman. ${ }^{62}$ (emphasis added) This formulation relaxes to a certain extent the rather demanding threshold enunciated earlier by the Ontario Court of Appeal in Chitel v. Rothbart wherein it was held that the applicant must establish a "real" risk of removal "clearly outside" the debtor's usual course of business "so as to render the possibility of future tracing of the assets remote, if not impossible in fact or law." ${ }^{63}$

The applicant must further establish that the debtor has assets within the jurisdiction which could be bound by the Mareva injunction. In the United Kingdom, the courts have required ". . . some grounds for believing that the defendants have assets . .." within the court's jurisdiction. ${ }^{64}$ In Canada, the Ontario Court of Appeal has demanded that the applicant "should establish [the] assets with as much precision as possible so that, if a Mareva injunction is warranted, it is directed towards specific assets or bank accounts."'s5 The Supreme Court of Canada made no comments on this requirement. There is British Columbia precedent which holds that once the Mareva injunction has been granted, the applicant may further apply for an order for the attendance and examination of the debtor in aid of
60. Id. at 35 S.C.R., 125 W.W.R.
61. Id. at 36 S.C.R., 126 W.W.R.
62. Id. at 25 S.C.R., 117 W.W.R.
63. Supra n. 40 at 289.
64. Third Chandris Shipping Corporation v. Unimarine S.A. [1979] 2 All E.R. 972 at 984 (C.A.).
65. Supra n. 40 at 289. 
enforcing the Mareva injunction. ${ }^{66}$ The British Columbia equivalent of Alberta Rule 379 was relied upon by the court in granting the order.

The Mareva injunction operates in personam, therefore it will only bind the debtor's assets subject to any pre-existing claims held against those assets. ${ }^{67}$ Consequently, the applicant will not obtain any priority over other unsecured creditors of the debtor. Furthermore, the Mareva injunction will not affect the priorities of the various claimants in cases where the debtor subsequently goes bankrupt, or where the debtor is a corporation in the process of dissolution. ${ }^{68}$ The effect of the Mareva injunction is merely to freeze the debtor's assets, not give the applicant some proprietary right in them.

Finally, it should be stressed that the Supreme Court's judgment in Feigelman evidences a cautious attitude taken by that court towards the Mareva injunction and its seemingly expanding usage. Mr. Justice Estey was notably concerned with the potential for "litigious blackmail" inherent in Mareva injunctions.$^{69}$ Even Lord Denning M.R., the father and perhaps biggest proponent of the Mareva, has opined that "Much as I am in favour of the Mareva injunction, it must not be stretched too far lest it be endangered."70 The practitioner should be aware of the increasingly conservative view which the courts have taken towards the Mareva injunction; practically speaking, this may translate into a higher burden for the applicant to discharge before successfully obtaining a Mareva injunction.

\section{The Alberta Court of Appeal's Comments}

The following comments focus around two main submissions. Firstly, it is submitted that a Mareva injunction should have been available in Bradley Resources, given the facts and the findings made by the Court of Appeal. Secondly, even though the court was of the opinion that a Mareva was not available, it is suggested that the type of relief actually granted was in effect a Mareva injunction.

With respect to the first submission, the reader should recall Mr. Justice Kerans' conclusion that a Mareva was not available, reasoning that "The mere fact of transfer of assets [from Alberta] to British Columbia should not trigger a Mareva injunction ..."' The learned Judge relied on the Supreme Court's judgment in Feigelman in arriving at this conclusion. While it is conceded that the mere transfer of assets from Alberta to British Columbia is not a sufficient ground by itself to grant a Mareva injunction, it is argued that the grounds necessary for obtaining a Mareva did exist on the facts.

As discussed earlier, the main issue in Feigelman was whether a removal of assets from one province to another justified the granting of a Mareva injunction. The Supreme Court concluded that a mere removal from one

66. Sekisui House v. Nagashima (1982) 33 C.P.C. 42 (B.C.C.A.).

67. Supra n. 2 at 25 S.C.R., 117 W.W.R.

68. Id. at 34 S.C.R., 124 W.W.R.

69. Id. at 37 S.C.R., 127 W.W.R.

70. Supra n. 64.

71. Supra n. 1 at 471 D.L.R., 766 W.W.R., 170 A.R., 195 Alta. L.R. 
province to another was not sufficient to support a Mareva application where the two provinces were reciprocating states pursuant to reciprocal enforcement of judgment legislation. Given that Alberta and British Columbia are reciprocating states, Kerans J.A. was correct in Bradley Resources in holding that the removal by Kelvin of all its corporate assets from Alberta to British Columbia did not "trigger" a Mareva injunction. However, it is respectfully submitted that Kerans J.A. should have gone one step further and examined whether there was a genuine risk that the assets would be dissipated within Alberta or British Columbia so as to stultify any judgment obtained by Bradley.

As mentioned earlier, the Supreme Court in Feigelman was primarily concerned with the definition of "removal from jurisdiction" in a federal context. However, Estey J. specifically acknowledged the availability of Marevas in situations involving dissipation within jurisdiction as well. ${ }^{2}$ The "overriding consideration", as his Lordship termed it, was whether the defendant would arrange his assets in such a manner so as to render any judgment against him nugatory. ${ }^{73}$ This arrangement of assets could be accomplished by removal from jurisdiction or dissipation within jurisdiction. It would appear as though the Alberta Court of Appeal construed the Feigelman decision as limiting the Mareva injunction to cases involving removal from jurisdiction as defined in that case. This is apparent from the court's failure to examine whether a risk of dissipation within jurisdiction was present.

When one asks whether a risk of dissipation within jurisdiction existed in the Bradley Resources case, it is quite clear that a Mareva injunction should have been granted. It should be recalled that the court in Bradley Resources found a "substantial risk" that Kelvin would dissipate its assets prior to judgment in a manner which would render Bradley's right to dissent meaningless. ${ }^{74}$ This finding, it is submitted, would be sufficient to support a Mareva injunction on the basis that there existed a genuine risk of dissipation within jurisdiction which if allowed to occur, would render any judgment against Kelvin nugatory. Therefore, although the transfer from Alberta to British Columbia was not enough by itself to support a Mareva injunction, it is quite apparent that there was a substantial risk of dissipation within Alberta or British Columbia which would have justified the granting of a Mareva injunction.

Having argued that a Mareva injunction should have been available to Bradley on the facts of the case, the next step is to examine the nature of the relief which was actually issued by the Court of Appeal. As discussed in Part II of this paper, the court was of the opinion that section 184 of the Business Corporations Act gave minority shareholders a significant new right. This right, the court thought, should not be allowed to be rendered meaningless by the actions of the majority shareholders. As discussed above, the court found a substantial risk that Bradley's right to dissent and have its shares redeemed would be effectively lost by the actions of those who controlled Kelvin. As a result, the court issued an injunction enjoining

72. See $\mathrm{nn} .57$ to 60 supra, and accompanying text.

73. Supra n. 2 at 24 S.C.R., 116 W.W.R.

74. Supra n. 1 at 472 D.L.R., 767 W.W.R., 172 A.R., 197 Alta. L.R. 
Kelvin "not to deal with the proceeds of the sale in any way without the prior approval of the court except to deposit them in an interest-bearing account ..."?

It is respectfully submitted that the order issued by the Alberta Court of Appeal was identical in purpose to a Mareva injunction. The purpose of the Mareva injunction is to prevent the defendant from dealing with his assets prior to judgment in such a manner as to stultify the effect of a judgment made against him. This was essentially the intendment of the order issued in Bradley Resources. In the words of Kerans J.A..$^{76}$

... [W] think it is a fit exercise of our undoubted power of injunction to interfere to assure Bradley, as against only the majority, that the award it ultimately receives as compensation for the decision of Kelvin to sell is not meanwhile rendered meaningless precisely because Kelvin decided to sell.

Kerans J.A. called the injunction a "form of special relief";" arguably, it is nothing more than a standard Mareva injunction. Both are intended to prevent the defendant from dealing with his assets so as to insulate himself 'from a judgment rendered against him.

Consequently, it could be argued that the "special relief" granted in Bradley Resources is nothing more than a specific application of the rationale underlying the Mareva injunction. There is much to be said for limiting the number of different types of interlocutory injunctions available. Afterall, we already have the Cyanamid injunction, the Mareva injunction and the quia timet injunction amongst others. Do we really need to add to the confusion by creating a Bradley injunction with its own unique guidelines and conditions when quite arguably the relief ordered was in effect a Mareva injunction? It would be much simpler for practitioners and the judiciary alike to prevent additions to the class, unless absolutely necessary. In Bradley Resources, such an addition was not necessary.

\section{CONCLUSION}

The general thesis of this paper has been that the Alberta Court of Appeal in Bradley Resources arrived at the right conclusion, but for the wrong reasons. As argued above, a Mareva injunction should have been granted, not because there was a removal from jurisdiction, but rather due to the finding that there was a substantial risk of dissipation within the jurisdiction. Paradoxically however, the relief eventually ordered by the court, even though not called a Mareva injunction, was quite arguably a Mareva injunction.

It is hoped that the Court of Appeal's judgment in Bradley Resources will not be interpreted by the courts or the bar as restricting the scope of Mareva injunctions to cases involving removal of assets from the jurisdiction of the court as defined by the Supreme Court in Feigelman. The intent of the Supreme Court was that interlocutory injunctive relief be available whenever there existed a genuine risk that the debtor would arrange his assets prior to judgment in such a manner as to cause his creditor

75. Id. at 472 D.L.R., 768 W.W.R., 172 A.R., 197 Alta. L.R.

76. Id. at 472 D.L.R., 767 W.W.R., 171 A.R., 197 Alta. L.R.

77. Id. 
irreparable harm. It should make no difference whether this was to be accomplished by a disposal of the assets within the court's jurisdiction or by removal beyond the court's jurisdiction. The Mareva injunction presently serves a much needed function in commerce and will continue to do so in the economically tough times ahead. Consequently, it is imperative that the Mareva's effectiveness not be reduced by an arbitrary distinction between removal from jurisdiction and dissipation within jurisdiction. The emphasis must be placed on the intended result of the defendant's dealings, not how they are to be carried out. 